\title{
ESO-1 (161-180) Peptide Vaccine
}

National Cancer Institute

\section{Source}

National Cancer Institute. ESO-1 (161-180) Peptide Vaccine. NCI Thesaurus. Code C28775

A recombinant 19-residue peptide vaccine consisting of amino acids 161 through 180 of the cancer/testis (CT) antigen. ESO-1 (161-180) peptide vaccine may stimulate the host immune system to mount a cytotoxic $T$ lymphocyte $(C T L)$ response ag ainst tumor cells positive for ESO-1, resulting in decreased tumor growth. ESO-1 is expressed in a variety of cancers, including melanoma, breast, bladder, prostate, and hepatocellular cancers. ( $\mathrm{NCl04)}$ 